\title{
Diagnosing embedded V2 in Old English and Old French
}

Christine Meklenborg Salvesen (University of Oslo) and George Walkden (University of Manchester)

NB: This is a an author accepted manuscript version reflecting changes made in the peer review and editing process, but not the publisher's PDF. This article will appear in Eric Mathieu and Rob Truswell (eds.), From micro-change to macro-change (Oxford: Oxford University Press). When citing, please use the page numbers given there. The publisher should be contacted for permission to re-use or reprint the material in any form.

\section{Introduction}

The goal of this paper is to discover the conditions under which embedded verbsecond (V2) was permitted in Old English and Old French, and to explore the theoretical implications of these conditions for the analysis of the landing site of the finite verb. ${ }^{1}$ Specifically, we seek to establish i) whether embedded $\mathrm{V}^{0}$-to- $\mathrm{C}^{0}$ movement is attested in $\mathrm{OE}$ and $\mathrm{OF}$, and, if so, ii) whether its occurrence in verbal complement clauses is constrained according to the class of the embedding verb in Hooper and Thompson's (1973) five-way typology.

Both OE and OF exhibit at least a strong tendency towards surface V2 in main clauses. ${ }^{2}$ For both $\mathrm{OE}$ and $\mathrm{OF}$, influential early generative treatments (e.g. van Kemenade 1987 for OE; Vanelli et al. 1985 and Adams 1987, 1989 for OF) proposed that the finite verb in such clauses was to be found in $\mathrm{C}^{0}-$ but for both languages this analysis has also been challenged (e.g. Pintzuk 1993, 1999 for OE; Dupuis 1989; Rinke and Meisel 2009 for OF), in favour of an analysis where the verb is in some lower position such as $\mathrm{I}^{0}$. The two families of analysis, which we will henceforth refer

\footnotetext{
${ }^{1}$ We would like to express our gratitude to the audiences of DiGS 15 and ICHL 21 as well as to two anonymous reviewers and the volume's editors for their helpful comments.

${ }^{2}$ This is one of the many apparently Germanic properties exhibited by OF; see Mathieu (2009) for an overview.
} 
to as $\mathrm{CP}$ and IP analyses respectively, differ in terms of a crucial prediction: while $\mathrm{CP}$ analyses predict the existence of an asymmetry between main and subordinate clauses, IP analyses predict that there should be no such asymmetry. It is this prediction that the present chapter sets out to test. We limit our study to embedded that-clauses, thus leaving other types of subordinate clauses for future research. Our point of departure is Hooper and Thompson's (1973) typology of verbs that take clausal complements, and we apply this to historical corpus data. To our knowledge, this has not been done before.

The chapter is structured as follows. Section 2 lays out the two families of analysis and their motivations in more detail, and explains how these predictions are derived. Section 3 describes our methodology, presenting Hooper and Thompson's (1973) typology of verb classes. Section 4 presents our results, and explores their implications. We conclude that, for both $\mathrm{OE}$ and $\mathrm{OF}, \mathrm{CP}$ analyses are better able to account for our data than IP analyses, but that there is a crucial difference between the two languages: OE does not permit embedded V2 at all, whereas OF permits it in some contexts. By relating this to the Merge site of finite complementizers, we link a micro-level parametric difference to the macro-level property of V2.

\section{Types and analyses of $\mathrm{V} 2$ in modern and historically-attested languages}

\subsection{Definitions}

Before we proceed, a word is in order on what we mean by V2. For us, the term is used in its 'surface' sense, to describe a structural configuration in which one and only one constituent precedes the finite verb, as in (1), and in which that constituent 
need not be the subject. ${ }^{3}$ A V2 language is then one in which this configuration predominates, and a strict V2 language is one in which it is exceptionless.

\begin{tabular}{|c|c|c|c|c|c|}
\hline $\begin{array}{l}\text { Den } \\
\text { the.ACC }\end{array}$ & $\begin{array}{l}\text { Mann } \\
\text { man.ACC }\end{array}$ & $\begin{array}{l}\text { hat } \\
\text { has }\end{array}$ & $\begin{array}{l}\text { der } \\
\text { the.NOM }\end{array}$ & $\begin{array}{l}\text { Hund } \\
\text { dog.NOM }\end{array}$ & $\begin{array}{l}\text { gebissen } \\
\text { bitten }\end{array}$ \\
\hline
\end{tabular}

\subsection{V2 in modern Germanic}

German, Dutch and the Mainland Scandinavian languages are all asymmetric V2 languages: as a general rule, V2 is restricted to main clauses, and is not possible in subordinate clauses (see Holmberg 2015: §2.4). Another group of Germanic languages, including Icelandic and Yiddish, are considered to be symmetric V2 languages in the sense that the verb is in second position in both main and subordinate clauses (see Santorini 1994). ${ }^{4}$ See Holmberg (2015) for detailed discussion of the V2 phenomenon in Germanic and beyond.

\section{(2) ASYMMETRIC V2 - NORWEGIAN}

(a) I går kom jeg for sent på jobb. In yesterday came I too late on work 'Yesterday, I was too late for work.'

(b) Jeg beklager at jeg kom for sent på jobb i går. I regret that I came too late on work in yesterday 'I regret that I was too late for work yesterday.'

(c) *Jeg beklager at i går kom jeg for sent på jobb.

(3) SYMMETRIC V2 - ICELANDIC

Jón harmar að pessa bók skuli ég hafa lesið

'John is sorry that I'll read this book.' $\quad$ (from Hrafnbjargarson and Wiklund 2009)

\footnotetext{
${ }^{3}$ A more theory-loaded definition is used by Poletto (2002), who sees V2 as a cover term to refer to any structural configuration in which the finite verb occupies a position in the C-domain.

${ }^{4}$ It is doubtful whether Icelandic, at least, is truly symmetric; see Maling (1980). It should also be noted that at least Icelandic seems to be restricted as to embedded topicalization in much the same way as the asymmetric V2 languages even though Icelandic permits more instances of embedded V2 than e.g. Mainland Scandinavian (see Hrafnbjargarson and Wiklund 2009 and references therein).
} 
The symmetric V2 languages have for the most part been analysed as involving the finite verb in $I^{0}$ in both main and subordinate clauses: see Diesing (1990) on Yiddish and Rögnvaldsson and Thráinsson (1990) on Icelandic. When it comes to the asymmetric languages, however, the main question has been how to derive the contrast between clause types without stipulation. The key insight came from den Besten (1977) and Evers (1981), who proposed that, in these languages, the finite verb was in complementary distribution with subordinating complementizers, with both in $\mathrm{C}^{0}$. This type of analysis, in which the finite verb occupies $\mathrm{C}^{0}$ in all main clauses, has been challenged by Travis $(1984,1991)$ and Zwart (1991, 1993), who argue that the verb only raises to $\mathrm{C}^{0}$ when a non-subject constituent is in initial position; when the subject is initial, it remains in SpecIP, and the verb remains in $\mathrm{I}^{0}$. The idea that the position of the finite verb depends on the nature of its preceding XP (subject vs. non-subject) is what we will refer to as the split hypothesis.

Schwartz and Vikner $(1989,1996)$ demonstrate that the split hypothesis faces a number of problems not shared by the consistent $\mathrm{V}^{0}$-to- $\mathrm{C}^{0}$ analysis, and as a result the majority of syntacticians today adopt a version of the latter, though Sells (2001) and Mikkelsen (2010) are exceptions. ${ }^{5}$ See Poletto (2002), Roberts (2004), Frascarelli and Hinterhölzl (2007), and Mohr (2009) for variants of the $\mathrm{V}^{0}$-to- $\mathrm{C}^{0}$ approach, which differ in implementation but share the basic insight that the position of the finite verb in main clauses is uniform.

To sum up: There are three competing analyses that can in principle account for V2 word order in main clauses: i) the IP analysis, claiming that the finite verb does not move higher than $\mathrm{I}^{0}$ and that the preceding element sits under SpecIP; ii) the $\mathrm{CP}$ analysis that claims that the finite verb sits under a head in the C-domain; and iii)

\footnotetext{
${ }^{5}$ More exotic analyses of V2 exist: see Fanselow (2003) and Müller (2004). We will not consider these here.
} 
the split hypothesis that suggests that the finite verb is in the C-domain when an XP other than the subject precedes it, and under $I^{0}$ when it is preceded by the subject. The analyses make differing predictions for subordinate clauses, which we will return to in section 2.5.

\subsection{V2 in Old English}

That OE has a high proportion of V2 main clauses has long been recognized (see e.g. Jespersen 1949). The analogy to the modern Germanic languages was first drawn in generative theory by Canale (1978) and van Kemenade (1987). However, OE differs from the modern languages in a number of ways: in particular, it exhibits a considerable number of V3 constructions. Most notably, with personal pronoun subjects, as in (4), main clauses are almost invariably V3; pronominal objects, some adverbs, and full nominal subjects as in (4) may also occupy this position. ${ }^{6}$

(4) æfter his gebede he ahof pæt cild up after his prayer he lifted the child up 'After his prayer he lifted the child up' (cocathom2,+ACHom_II,_2:14.70.320)

\begin{tabular}{|c|c|c|c|c|c|c|c|}
\hline $\begin{array}{l}\mathrm{Nu} \\
\text { now }\end{array}$ & $\begin{array}{l}\text { se } \\
\text { the }\end{array}$ & $\begin{array}{l}\text { rica } \\
\text { rich }\end{array}$ & $\begin{array}{l}\operatorname{mann} \\
\operatorname{man}\end{array}$ & $\begin{array}{l}\text { ne } \\
\text { NEG }\end{array}$ & $\begin{array}{l}\text { mag } \\
\text { can }\end{array}$ & $\begin{array}{l}\text { her } \\
\text { here }\end{array}$ & $\begin{array}{l}\text { habban ... } \\
\text { have ... }\end{array}$ \\
\hline
\end{tabular}

These data have been taken to motivate an analysis in which the verb is typically in the IP domain, for instance in Pintzuk (1993, 1999), Eypórsson (1995), Haeberli (1999, 2002, 2005), Fuß (2003), and Speyer (2008, 2010). If the verb does not evacuate the I-domain, the prediction is that there will be no main-embedded asymmetries. Other authors, however, have pointed to the possibility of an expanded

\footnotetext{
${ }^{6}$ There are also examples in which the verb occurs in a later position: see Koopman (1995), Pintzuk and Haeberli (2008), and Walkden (2014: 94-106).
} 
CP layer following Rizzi (1997) as an alternative way of accounting for some of these patterns; these include Roberts (1996), Westergaard (2005), Hinterhölzl and Petrova (2009), and Walkden $(2009,2014){ }^{7}$ We refer the reader to Walkden $(2014: \mathrm{ch} .3)$ for more discussion of the range of constituent orders to be found in OE main clauses.

\subsection{V2 in Old French}

As for OE, the idea that OF is fundamentally a V2 language has a long pedigree, going back at least to Thurneysen (1892). Adams (1987, 1989) and Roberts (1993) are two influential early generative analyses exploiting the idea that the verb is in the Cdomain. When an XP other than the subject precedes the finite verb, the subject is postverbal (6).

(6) Lors oste mes sires Gauvains son hiaume de sa teste then removes my sire Gauwain his helmet of his head 'Then Sir Gauwain removes the helmet from his head.' (Graal, 165d, 127)

There is no consensus as to the position of the finite verb in main clauses: Vance (1997), Labelle (2007) and Labelle and Hirschbühler (this volume) are proponents of the split hypothesis, whereas in the analyses of Vanelli et al. (1985), Adams (1987, 1989), Roberts (1993), Benincà (2006), Vance et al. (2010), Salvesen (2013), and Steiner (2014) there is always $\mathrm{V}^{0}$-to- $\mathrm{C}^{0}$-movement.

OF does, however, display numerous exceptions to the V2 rule, in general by allowing V3 structures. These are quite homogeneous in the sense that the initial XP is either a subordinate adverbial clause (Vance et al. 2010, Donaldson 2012a, 2012b; Radwan 2012; Salvesen 2013; Bech and Salvesen 2014) or belongs to a small set of

\footnotetext{
${ }^{7}$ Recent work by van Kemenade and co-authors discussing information-structural variation in subject positions, e.g. van Kemenade and Milićev (2012) and van Kemenade and Westergaard (2012), proposes that the verb moves to the head of a functional projection FP, but is neutral as to whether this projection is in the C-domain or below it. Our data support the view that FP is in the C-domain.
} 
adverbials (Vance 1997; Bech and Salvesen 2014). Examples that are not captured by this generalization are not widespread in the $13^{\text {th }}$ century. Example (7) shows a fronted subordinate adverbial clause followed by S-V word order. ${ }^{8}$

Et quant il fu auques anuitié et il fu hore de dormir li
and when he was some begun-night and it was hour of sleep the
rois prist Galaad et l'enmena en sa chambre
king took Galahad and him=brought in his chamber
'And when the night had started to fall and it was time to sleep, the king took Galahad and
brought him into his own chamber.'
(OF;Graal 164d 17)

As a fronted subordinate adverbial clause may be followed either by a S-V structure or (rarely) a V2 structure, these clauses have been analysed as occupying a specifier position to the left of the V2 scheme, probably the specifier of the Scene Setting position in the sense of Benincà and Poletto (2004) (see Donaldson 2012a; Salvesen 2013; Bech and Salvesen 2014). In the cases where the fronted subordinate clause is followed by the finite verb and (optionally) the subject, it must be analysed as the first element in the V2 structure. This implies that it occupies a different position than in the cases where it does trigger a V3 word order.

The standard description of OF says that it is an asymmetric V2 language, and that subordinate clauses have S-V word order (8).
(8) Et il dient que ce est voirs and they say that this is true 'and they say that this is true'

In this paper we will show that embedded V2 in OF is fairly common, and we will examine these structures more thoroughly.

\footnotetext{
${ }^{8}$ The main clause following a fronted subordinate adverbial clause may also be introduced by the particle $s i$, especially if the two clauses contain the same subject (Schøsler and van Reenen 2000).
} 


\subsection{Embedded clauses: a neglected domain}

If we assume, standardly, that complementizers originate in the C-domain, the predictions made by the two families of analysis are clear (Haeberli 2005: 273-274). All IP analyses predict that XP-V-(S) word order should be as prevalent in subordinate clauses as in main clauses, whereas $\mathrm{CP}$ analyses predict a clear asymmetry. IP analyses also predict that V1 structures should be possible in subordinate clauses. ${ }^{9}$ In addition, Pintzuk's $(1993,1999)$ IP analysis of OE and Dupuis's (1989) and Rinke and Meisel's (2009) IP analyses of OF, since they treat SpecIP as an A'-position that can host any constituent, predict that V2 should be possible in all subordinate clause types, as should embedded topicalization. By contrast, the 'split' IP analyses (for OE see Eypórsson 1995; Haeberli 1999, 2002, 2005; Fuß 2003; and Speyer 2008, 2010; for OF see Vance 1997, Labelle 2007, Labelle and Hirschbühler this volume), in which SpecIP is not an A'-position but where the finite verb moves to a head in the I-domain, predict that embedded topicalization and non-subject-initial V2 should be ruled out under certain predicates, as do the CP analyses mentioned above. Following Vikner (1995: 65), asymmetric V2 languages can be divided into two subclasses: languages such as standard German, which prohibit embedded V2 whenever the complementizer is present, and languages such as Mainland Scandinavian, which permit embedded V2 with an overt complementizer only in specific contexts. ${ }^{10}$ In particular, embedded V2 is ruled out in these languages in complement clauses of verbs that are not 'bridge' verbs (Vikner 1995; see also Andersson 1975; Green 1976; Julien 2009).

\footnotetext{
${ }^{9}$ Pintzuk (1999: 223) acknowledges this problem. Haeberli (2005) is able to evade it by positing, like CP analyses, that the verb moves higher in main clauses (to $\mathrm{AgrS} \mathrm{S}^{0}$ ) than in subordinate clauses $\left(\mathrm{T}^{0}\right)$.

${ }^{10}$ In German, embedded V2 is the only possibility when the complementizer is not expressed.
} 
In this paper we aim to investigate the possibilities of embedded V2 in OE and OF. If embedded V2 exists, is the occurrence of such constructions limited to certain contexts? Instead of evoking the rather blurry term of bridge verb (Vikner 1995; see also Andersson 1975; Green 1976), ${ }^{11}$ we will use Hooper and Thompson's (1973) classification of different types of verbs that take finite complement clauses. We take all instances of XP-V-S as an instance of V2 and do not consider Leftward Stylistic Fronting in the sense that has been proposed by Labelle and Hirschbühler (this volume).

\section{Investigating complement clauses}

\subsection{Classes of complement-taking verb}

'Main clause phenomena' (Emonds 1970; Green 1976) are found in the complements of some verbs, but not others. These main clause phenomena include Negative Constituent Preposing, as in (9) and (10), as well as VP preposing, topicalization, and more. (10) shows that main clause phenomena are ruled out at least in some subordinate clauses.

(9) He's been out of work before, but never has he had to borrow money.

(10) *The fact that never has he had to borrow money makes him very proud.

To account for the empirically observed distribution of main clause phenomena, Hooper \& Thompson (1973) divide complement-taking verbs into five classes, labelled A-E, according to the discourse status of their complement clauses: strong

\footnotetext{
${ }^{11}$ Vikner himself notes (1995: 70, fn. 7) that the notion of bridge verb is problematic: in particular, the term was introduced to denote verbs that did not permit extraction from their complement, and this does not always correlate with permitting embedded V2. See Biberauer (2002) and Julien (2007) for two critical views.
} 
assertive verbs (Class A), weak assertive verbs (Class B), verbs that are neither assertive nor factive (Class C), factive verbs (Class D), and semifactive verbs (Class E).

Class A verbs in Hooper and Thompson's schema introduce strong assertions, and are typically verbs of saying, e.g. say, report, exclaim, assert, claim, vow, be true, be certain, be sure, be obvious. Class B verbs introduce weak assertions, and are typically verbs denoting mental processes: examples are suppose, believe, think, expect, guess, imagine, it seems, it happens, and it appears. Hooper and Thompson (1973) find that members of both these classes allow main clause phenomena in their complement clauses. The clauses in (11) both contain a topicalized element.

Root: Most embarrassing of all was falling off the stage.

(a) Class A: Carol said that most embarrassing of all was falling off the stage.

(b) Class B: I suppose that most embarrassing of all was falling off the stage.

In contrast to classes $\mathrm{A}$ and $\mathrm{B}$, verbs of class $\mathrm{C}$ select complements that are not asserted. In English these are verbs such as be (un)likely, be (im)possible, be (im)probable, doubt, and deny. Hooper and Thompson show that main clause phenomena never occur in the complements of Class C verbs (12).

(12) Class C: *It's unlikely that most embarrassing of all was falling off the stage.

The class D factive verbs resent, regret, be sorry, be surprised, bother, be odd, be strange, be interesting select complements that are presupposed, and typically express an emotion or subjective attitude. Class E verbs also select presupposed complements, 
and are referred to as semifactive (Karttunen 1971); they include realize, learn, find out, discover, know, see, and recognize, and typically 'assert the manner in which the subject came to know that the complement proposition is true' (Hooper and Thompson 1973: 480).

Hooper and Thompson find that main clause phenomena are not permitted in the complements of Class D verbs. As for complements of Class E verbs, however, they allow root phenomena, but only when the complement is asserted. The generalization that emerges is that main clause phenomena are possible in asserted complement clauses only.

(13) Root: She opened the window and in flew Peter Pan.

(a) Class D: *Wendy was sorry that she opened the window and in flew Peter Pan.

(b) Class E: Tinker Bell saw that Wendy opened the window and in flew Peter Pan.

Julien (2009) applies their diagnostics to the issue of embedded V2 using corpora of Norwegian, Danish and Swedish. In all cases, she finds that the contexts in which embedded V2 is permitted are exactly those that count as asserted using Hooper and Thompson's criteria, i.e. complements of verbs of classes A, B and E. Our prediction is therefore that, insofar as we find embedded V2 in OE and OF, it should be restricted to these contexts.

\subsection{Our methods}

The corpus used for OE was the York-Toronto-Helsinki Parsed Corpus of Old English Prose (YCOE; Taylor et al. 2003). From this corpus we took an exhaustive sample of complement clauses with surface order (non-nominative-) XP-V-... In 
addition, a sample of 881 other complement clauses was taken. ${ }^{12}$ For OF, the Base $d u$ Français Médiévale (BFM; Heiden et al. 2010) was used, and all verbal complement clauses from the text La Queste de Graal were analysed (879 in total).

We then classified all matrix predicates as falling under one of Hooper and Thompson's (1973) five categories. Applying this typology to OE and OF was not entirely straightforward, since more verbs in $\mathrm{OE}$ and $\mathrm{OF}$ take finite clausal complements than in their modern counterparts. In particular, verbs of 'volition', as in (14) and (15), are difficult to fit into the system. In Modern English, these verbs take non-finite complements, as shown by the translations.

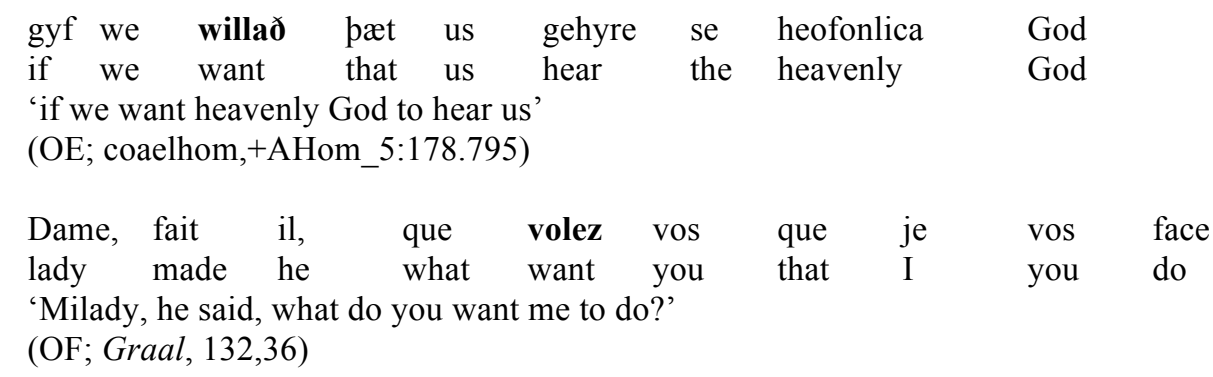

The complements of these verbs seem to be neither asserted nor presupposed, but express the protagonist's attitude towards a hypothetical state of affairs. In both $\mathrm{OE}$ and OF these clauses typically take the subjunctive mood. For the purposes of our study, we have chosen to treat these 'volitives' as a separate group, Class V.

\footnotetext{
${ }^{12}$ Given that the YCOE is not lemmatized and a search for these other complement clauses turned up 13,407 examples, an exhaustive manual analysis of non-V2 clauses was not undertaken for reasons of time. Instead, a sample of non-V2 clauses was randomly selected for further analysis.
} 


\section{Results and discussion}

\subsection{Breakdown of results by verb class}

The overall distribution of V2 clauses by embedding predicate type is given in Table $1 .^{13}$

Table 1: Embedded V2 in OE and OF by class of embedding predicate: overall results

\begin{tabular}{l|llllll} 
& $\begin{array}{l}\text { Old } \\
\text { English }\end{array}$ & \multicolumn{5}{c}{$\begin{array}{l}\text { Old } \\
\text { French }\end{array}$} \\
\hline & Total & V2 & \% & Total & V2 & \% \\
A & 476 & 172 & $3.6 \%$ & 286 & 78 & $28.0 \%$ \\
B & 230 & 93 & $4.3 \%$ & 196 & 18 & $9.2 \%$ \\
C & 14 & 5 & $3.5 \%$ & 0 & 0 & $0.0 \%$ \\
D & 96 & 13 & $1.0 \%$ & 35 & 0 & $0.0 \%$ \\
E & 280 & 123 & $4.9 \%$ & 235 & 24 & $10.2 \%$ \\
V & 240 & 49 & $1.7 \%$ & 127 & 1 & $0.8 \%$ \\
Total & $\mathbf{1 3 3 6}$ & $\mathbf{4 5 5}$ & $\mathbf{3 . 3 \%}$ & $\mathbf{8 7 9}$ & $\mathbf{1 2 1}$ & $\mathbf{1 3 . 8 \%}$
\end{tabular}

It is, however, uninstructive to compare the different classes of embedding verbs without taking into account the type of embedded verb, since we know that several types of constructions will merge the DP subject in a low position that may cause it to surface postverbally. This is the case for unaccusative and impersonal verbs, passive, presentative, and modal constructions, and clauses with copulas (see in particular van Kemenade 1997 for OE, and Legendre and Sorace 2003 for Modern Romance). If we assume that there is no requirement for the DP subject to evacuate the $v \mathrm{P}$ domain, these embedded verbs may therefore have a postverbal DP subject without verb movement to the C-domain (Salvesen and Bech 2014), yielding a surface V2 word

\footnotetext{
${ }^{13}$ For OE, the italicized percentages in Tables 2 and 3 are estimates reached by assuming that the proportions of the different
} classes represented in the non-V2 sample can be extrapolated to all 13,407 non-V2 clauses. 
order which we label accidental V2. Therefore, these kinds of clause have been left out. We have also excluded embedded clauses with a pro subject in OF, even though pro is often seen as an indication of $\mathrm{V}^{0}$-to- $\mathrm{C}^{0}$ movement in main clauses (Adams 1987, Vance 1989, 1997, Roberts 1993). The reason for this is that there are known cases where pro may occur without $\mathrm{V}^{0}$-to- $\mathrm{C}^{0}$ movement (Hirschbühler and Junker 1988, Ingham 2012; Salvesen 2014a). ${ }^{14}$ When we leave out these groups, we get a set of clauses that are clearly instances of embedded V2.

Table 2: Embedded V2 in OE and OF by class of embedding predicate: only non-accidental V2

\begin{tabular}{l|rrrrrr} 
& \multicolumn{1}{l}{$\begin{array}{l}\text { Old } \\
\text { English }\end{array}$} & \multicolumn{7}{c}{ Old French } \\
& Total & V2 & \% & Total & V2 & \% \\
A & 476 & 11 & $0.2 \%$ & 286 & 60 & $21.0 \%$ \\
B & 230 & 6 & $0.3 \%$ & 196 & 6 & $3.1 \%$ \\
C & 14 & 0 & $0.0 \%$ & 0 & 0 & $0.0 \%$ \\
D & 96 & 2 & $0.2 \%$ & 35 & 0 & $0.0 \%$ \\
E & 280 & 8 & $0.3 \%$ & 235 & 12 & $5.1 \%$ \\
V & 240 & 2 & $0.1 \%$ & 127 & 0 & $0.0 \%$ \\
Total & $\mathbf{1 3 3 6}$ & $\mathbf{2 9}$ & $\mathbf{0 . 2 \%}$ & $\mathbf{8 7 9}$ & $\mathbf{7 8}$ & $\mathbf{8 . 9 \%}$
\end{tabular}

We see that in OF there are no instances of embedded V2 after Class C or D predicates. Even though we do not have any occurrences of Class $\mathrm{C}$ verbs in the $\mathrm{OF}$ data, the differences observed in table 2 are statistically significant: a Fisher's exact test (Fisher 1922) for classes A, B, E, and V vs. C and D gives us $p=0.03615$. In OE, the difference between classes A, B, E, and V and classes C and D is not significant

\footnotetext{
${ }^{14} \mathrm{OE}$ examples where it is clear that no overt subject is present (instances of subject extraction from the subordinate clause, as well as eleven instances of referential null subjects) were also excluded from the V2 figures in Table 2, as it is not clear that these do not also involve accidental V2. Italicized figures for OE are extrapolated estimates.
} 
$(\mathrm{p}=1)$, apparently because embedded $\mathrm{V}^{0}$-to- $\mathrm{C}^{0}$ as a whole is incredibly infrequent with all classes of verbs: in no class does it occur more than $0.3 \%$ of the time.

\subsubsection{Class A predicates}

In OE most tokens of Class A verbs involve secgan and cweðan 'to say', including 9 of the 11 cases of embedded V2.
(16) ac hit wæs openlice gecyped, pæt his forðfore but it was openly said that his death begeat seo pingung pæs arwyrðan Anastasies obtained the intervention the.GEN venerable A. 'But it was openly said that the intervention of the venerable Anastasius caused his death' (OE; cogregdC,GD_1_[C]:8.53.29.608)

In OF, $21 \%$ of the clauses attached to a Class A predicate display V2. The vast majority of these (51 of 60$)$ are attached to the verb dire 'say'.

(17) Or dit li contes que .iii. jorz fist li preudons Lancelot demorer o lui now says the story that four days made the prud'homme Lancelot stay with him 'Now the story tells you that the gentleman made Lancelot stay with him for four days.' (OF; Graal col 187s, 13 )

\subsubsection{Class B predicates}

In OE, Class B verbs include geliefan 'to believe', as in (18), and limpan 'to happen', and in OF cuidier 'believe', avenir 'happen' and sembler 'seem'.
(18) pæt pu gelyfe, pæt pa wipercorenan bærnep pæt that you believe that the.ACC against-chosen.ACC burns the ece fyr of pam dæge heora ændes and forðfore eternal fire from the day their.GEN end.GEN and death 'that you believe that the wicked are burned by eternal fire from the day of their death' (OE; cogregdC,GDPref_and_4_[C]:29.303.14.4509)

(19) Si m' en est si bien puis avenu que mout $i$ ai gaaingnié SI me of-it is so well then happened that much there have.1PS won 'And it all turned out so well for my part that I won a lot there.' (OF; Graal col 173a 136) 
et bien $i$ paroit a ce qu' il avoit le jor fet que d' iluec en and well there seemed of that what he had that day done that of here in avant porroit il legierement sormonter de proece tozles autres chevaliers forward could he easily surmount of prowess all the other knights 'And based on what he had done that day, it seemed likely that he would easily surpass the boldness of all the other knights in the future.'

(OF; Graal col 163a 132)

In (20), the matrix verb is paroir 'seem', and the subject of the embedded clause is the personal pronoun il 'he'. There is a long tradition among OF linguists to consider the postverbal personal pronoun as enclitic to $C^{0}$ (Roberts 1993, Vance 1997). Thus, the construction in (20) strongly indicates that there is $\mathrm{V}^{0}$-to- $\mathrm{C}^{0}$ movement.

\subsubsection{Class C predicates}

Hooper and Thompson's Class $\mathrm{C}$ is incredibly rare in our corpora: there are no examples for $\mathrm{OF}$, and only 14 in total for $\mathrm{OE}$. In neither language is there a single example of unambiguous V2: (21) below, from OE, appears to be one, but this is an instance of a passive with a low nominative, and hence accidental V2 (see van Kemenade 1997: 335).

(21) Forpon se ylca wer wiðsoc, pæt him moste beon ænigu nydpearfnes gepegnod therefore the same man denied that him must be any need served 'Therefore that man denied that there was any need for him to be served' (OE; cogregdC,GDPref_and_4_[C]:12.276.9.4027)

\subsubsection{Class D predicates}

In $\mathrm{OE}$, of the 96 examples of clauses embedded under Class D predicates, only two appear to contain embedded V2, and both are embedded under the same predicate in the same sentence. The offending example is given in (22) below. 


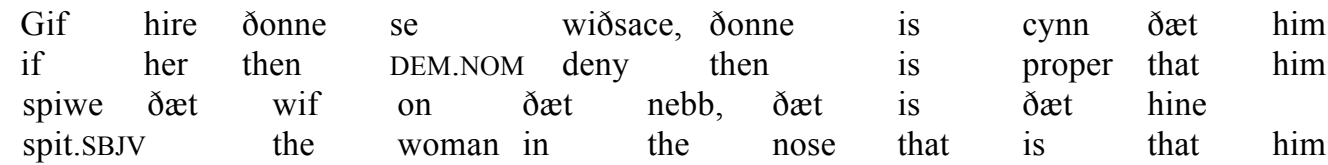
tæle ðæs folces gesomnung

blame.SBJV the.GEN people.GEN assembly

'If he then denies her, then it is proper that the woman should spit in his face, that is, that the people's assembly should blame him'

(OE; cocura,CP:5.45.2.249)

These clauses are the only two counterexamples in our corpora to the claim that nonaccidental embedded V2 is ruled out with verbs of classes C and D. Moreover, the predicate here - cynn wesan 'to be suitable/proper' - is classified as D because it expresses an emotion/attitude, like Hooper and Thompson's (1973) examples be interesting and be strange; it could also be classified as A, parallel to Hooper and Thompson's (1973) classification of be obvious. In any case, this sentence alone cannot be taken to indicate that embedded V2 was a productive possibility in OE.

In OF, there are no instances of embedded root phenomena after a Class D predicate. Class D verbs are, however, attested. This group typically include douter 'fear', plaisir 'please' and soffrir 'suffer'.

\subsubsection{Class E predicates}

In OE, seon 'to see', witan 'to know' and ongietan 'to perceive/understand' account for most of the Class E predicates. In OF, we find verbs such as savoir 'know', conoistre 'know', veoir 'see' and oï 'hear'. The verbs savoir and veoir are the most common verbs to embed a V2 subordinate clause, with 10 and 9 clauses respectively.

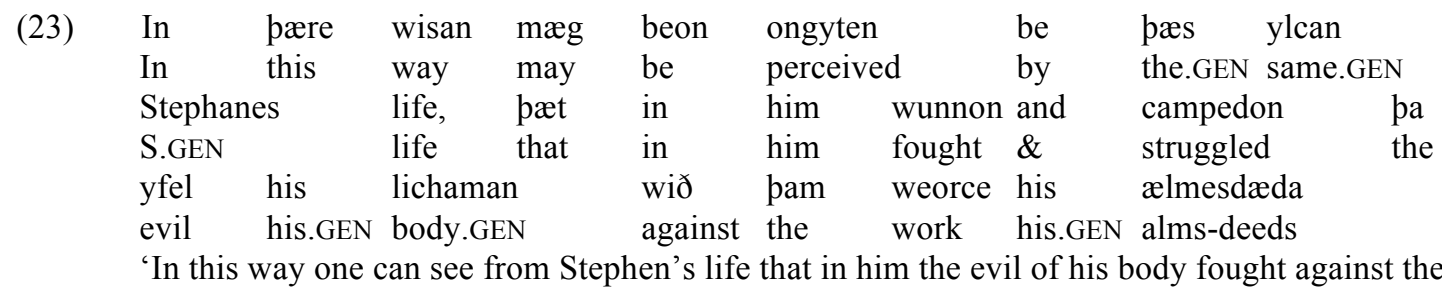


works of his charitable deeds'

(OE; cogregdC,GDPref_and_4_[C]:37.320.16.4809)

(24) car tu sez bien que la fille le roi Pellés coneus tu charnelment for you know well that the daughter the king Pelleas knew you carnally 'For you know well that you were intimate with the daughter of the king Pelleas' (OF; Graal, col 192d, 1. 30)

\subsubsection{Class V predicates}

In the YCOE there are only two unambiguous examples of embedded V2 under class V predicates; (25) is one of them.

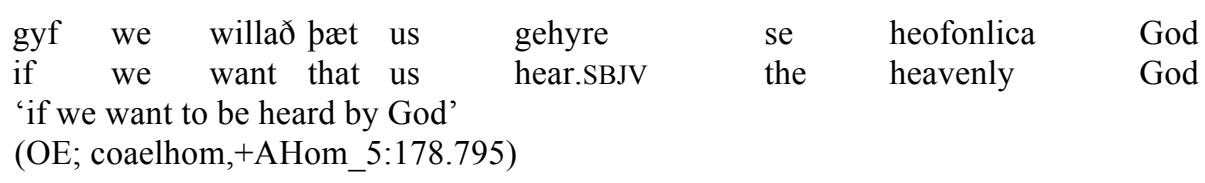

In OF, there are no unambiguous examples of embedded V2 after Class V predicates.

\subsection{Analysis: embedded V2 and the complementizer}

Our results show a difference in behaviour between OE and OF: while in OF, embedded V2 appears to be possible under certain predicates but not others, much as in Mainland Scandinavian (Julien 2009), in OE embedded V2 is completely ruled out, much as in modern German, with only a handful of non-accidental counterexamples $(0.2 \%)$. For both OE and OF, we would expect embedded V2 to be generally productive with all types of embedding predicates under a pure IP analysis, since SpecIP is an $\mathrm{A}^{\prime}$-position. Our data falsify this prediction, indicating that only a $\mathrm{CP}$ analysis, or a 'split' IP analysis, is realistic.

Why do certain types of verbs permit V2 word order in the subordinate clause in OF whereas others seem to prohibit this? Using Rizzi's (1997) model of an exploded CP, we will argue that the difference is caused by the verb's selectional 
properties: Verbs permitting embedded root phenomena select a larger phrasal unit headed by a higher complementizer - presumably under Force ${ }^{0}$. Verbs that do not permit embedded root phenomena select a smaller phrasal unit headed by a lower complementizer presumably merged under Fin ${ }^{0}$. This is in the same vein as analyses proposed by Roberts (2004), Benincà and Poletto (2004), Rouveret (2004), Paoli (2006), Villa-García (2012), Ledgeway (2012), Dagnac (2012), just to mention a few.

Under the CP analysis we would thus expect to find an asymmetry between different types of verbs with respect to embedded root phenomena. This asymmetry would be unexpected under the IP analysis. We thus believe that the distribution we find, where embedded V2 does not occur under predicates of types C and D, indicates that main clause constituent order involves verb movement to the $\mathrm{CP}$ layer.

\subsection{Embedded $V 2$ in $\mathrm{OF}$}

We argue that in OF there are two options for the CP where ForceP is projected:

Either the complementizer is merged under Fin $^{0}$ and moved by standard head

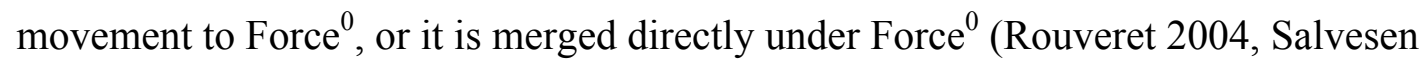
2014b). In the former case the subordinate clause crucially has a S-V structure with the subject under SpecTP (or enclitic to Fin ${ }^{0}$, see Vance 1997). In certain cases there may be material in the $\mathrm{CP}$ field which is preceded and followed by a complementizer (in boldface) - known as complementizer doubling (CD) (26). ${ }^{15}{ }^{16}$ In cases where no

\footnotetext{
${ }^{15}$ As complementizer doubling implies the selection of a higher complementizer (under Force ${ }^{0}$ ), we could have chosen to include these in our tables as they too provide information about the selectional properties of the matrix verb. For reasons of clarity we have chosen to limit this paper to the discussion of unambiguous V2 cases.

${ }^{16}$ See also Ribeiro and Torres Morais (2012) for Old Portuguese. These examples are occasionally found for OE too, though are rare:

(i) Wel mæg gehwa witan pæt gif ahwær is myrcð and wuldor well may each know that if anywhere is mirth and glory pæt pær is unasecgendlic wuldor pær se wuna pe ealle ðincg gesceop that there is unspeakable glory where he lives who all things shaped 'All may well know that if there is mirth and glory anywhere, there is incredible glory where he who created all things lives' (OE; coaelive,+ALS[Ash_Wed]:92.2751)
} 
slots in the left periphery are filled, the complementizer is merged under Force ${ }^{\circ}$, leaving Fin ${ }^{\circ}$ open for $\mathrm{V}^{\mathrm{o}}$-to- $\mathrm{C}^{\mathrm{o}}$-movement (27). This gives us the structure in (28) for the cases under discussion in this paper (excessive structure omitted).

(..) car vos savez bien que quant vos alastes a cort que mes sires
$\begin{array}{llllll}\text { (..) for you know well that when you went to court that my sir } \\ \text { sires li } & \text { rois avoit guerre contre le } & \text { roi } & \text { Libran } & \\ \text { sir the king had } & \text { war against the } & \text { king Libran }\end{array}$
'for when you went to court, you knew well that the king was at war with king Libran.' (OF; Graal, col. 178d, 1. 26)

Et il respont que ce ne feroit il pas.
and he responded that that NEG does he NEG
'And he replied that he would not do that.'
(OF; Graal, col. 183a, 1.40)

[Forceo que $\left[\right.$ SpecFinP ce $\left[\right.$ Fin $^{\circ}$ ne feroit (...)]]]

If we consider the different subtypes discussed here, we see that they all represent different kinds of root phenomena and that these may be linked to the presence of a high complementizer. In structures that express two complementizers, the word order is always $\mathrm{S}-\mathrm{V}$. When only the higher complementizer is expressed, it is possible to get V2 structures following the initial element. Both kinds of root phenomena show the same pattern as we did when we only considered V2: they exclusively appear after verbs of classes A, B, E and V.

\subsection{Embedded $V 2$ in $O E$}

Finally, OE, as we have seen, basically disallows embedded V2 entirely. The microparametric difference between $\mathrm{OE}$ and $\mathrm{OF}$ - the same that distinguishes German and Mainland Scandinavian - can be captured lexically if we assume that there is no high complementizer in OE: all complementizers are first merged in Fin ${ }^{0}$. Whether or not the complementizer remains there, its lower copy will then block verb movement 
to the left periphery. ${ }^{17}$ While there are traces of the structure found in OF - a handful of examples of apparently non-accidental embedded V2, and double-complementizer structures - it does not seem to be a productive possibility in OE.

\section{Conclusion}

In this paper we have tested the predictions of two families of analyses of $\mathrm{OE}$ and $\mathrm{OF}$ with respect to embedded V2. IP analyses predict that embedded V2 should occur freely, as has been argued for Icelandic and Yiddish - a prediction that is false for both OE and OF. By contrast, CP analyses (and 'split' analyses) predict that embedded V2 should either a) be ruled out entirely except where accidental, or b) occur only under specific types of predicate. Using Hooper and Thompson's (1973) typology of predicate classes, we found that OE, like modern German, instantiates option a): non-accidental embedded V2 is vanishingly rare. OF, like the modern Mainland Scandinavian languages, instantiates option b), allowing embedded V2 only under certain predicates. We link this difference to the site of first Merge of complementizers in the two languages.

\section{References}

Adams, Marianne (1987). 'From Old French to the theory of pro-drop', Natural Language and Linguistic Theory 5, 1-32.

Adams, Marianne (1989). 'Verb second effects in Medieval French', in C. Kirschner and J. DeCesaris, (eds), Studies in Romance linguistics: selected papers from the seventeenth Linguistic Symposium on Romance Languages. Amsterdam: John Benjamins, 1-33.

Andersson, Lars-Gunnar (1975). Form and function of subordinate clauses. Ph.D. dissertation. Göteborg University.

\footnotetext{
${ }^{17}$ A reviewer questions what happens in cases of $\mathrm{OE}$ relative clauses in which the relative pronoun is in SpecFinP and there is no overt complementizer. In these cases, the finite verb might be predicted to move to Fin ${ }^{0}$; however, embedded V2 is vanishingly rare in such contexts as it is in other relative and complement clauses with an overt complementizer. This problem in fact exists for all accounts that seek to translate the den Besten (1977) intuition into X'-theoretic terms (cf. Richter \& Sailer 1998). We do not have a solution at present.
} 
Bech, Kristin, and Christine Meklenborg Salvesen (2014). 'Preverbal word order in Old English and Old French', in Kristin Bech and Kristine G. Eide (eds), Information structure and syntactic change in Germanic and Romance languages. Amsterdam: John Benjamins, 233-270.

Benincà, Paola (2006). 'A detailed map of the left periphery in medieval Romance', in Raffaella Zanuttini, Héctor Campos, Elena Herburger, and Paul Portner (eds), Cross-linguistic research in syntax and semantics: negation, tense and clausal architecture. Washington, DC: Georgetown University Press, 53-86.

Benincà, Paola, and Cecilia Poletto (2004). 'Topic, focus, and V2', in Luigi Rizzi (ed), The cartography of syntactic structures, vol 2: The structure of CP and IP. Oxford: Oxford University Press, 52-75.

Biberauer, Theresa (2002). 'Reconsidering embedded verb second: how 'real' is this phenomenon?', Cambridge Occasional Papers in Linguistics 8, 25-60.

Canale, William M. (1978). Word order change in Old English: base reanalysis in generative grammar. Ph.D. dissertation. McGill University.

Dagnac, Anne (2012). 'How do you double your C? Evidence from an Oïl dialect', in Christopher Pinon (ed), Empirical Issues in Syntax and Semantics 9. Paris: CNRS, p. 77-94.

den Besten, Hans (1977). On the Interaction of Root Transformations and Lexical Deletive Verbs. Ms. University of Amsterdam.

Diesing, Molly (1990). 'Verb movement and the subject position in Yiddish', Natural Language and Linguistic Theory 8, 41-79.

Donaldson, Bryan (2012a). 'Initial subordinate clauses in Old French: syntactic variation and the clausal left periphery', Lingua 122, 1021-1046.

Donaldson, Bryan (2012b). Diachronic change in Old French clause structure: effects on initial subordinate clauses. Ms. University of Texas at Austin.

Dupuis, Fernande (1989). L'expression du sujet dans les subordonnées en ancien français. Ph.D. dissertation. Université de Montréal.

Emonds, Joseph (1970). Root and structure-preserving transformations. Ph.D. dissertation. MIT.

Evers, Arnold (1981). 'Verb-second movement rules', Wiener Linguistische Gazette 26, 15-34.

Eypórsson, Pórhallur (1995). Verbal syntax in the early Germanic languages. Ph.D. dissertation. Cornell University.

Fanselow, Gisbert (2003). 'Münchhausen-style head movement and the analysis of verb-second', in Anoop Mahajan (ed), Syntax at sunset: head movement and syntactic theory. UCLA Working Papers in Linguistics, 40-76.

Fisher, Ronald A (1922). 'On the interpretation of $\chi^{2}$ from contingency tables, and the calculation of P', Journal of the Royal Statistical Society 85, 87-94.

Frascarelli, Mara, and Roland Hinterhölzl (2007). 'Types of topics in German and Italian', in Kerstin Schwabe and Susanne Winkler (eds), On information structure, meaning and form: Generalizations across languages. Amsterdam: John Benjamins, 87-116.

Fuß, Eric (2003). 'On the historical core of V2 in Germanic', Nordic Journal of Linguistics 26, 195231.

Green, Georgia M (1976). 'Main clause phenomena in subordinate clauses', Language 52, 382-397.

Haeberli, Eric (1999). Features, categories and the syntax of A-positions. PhD dissertation. University of Geneva.

Haeberli, Eric (2002). 'Inflectional morphology and the loss of V2 in English', in David Lightfoot (ed), Syntactic effects of morphological change. Oxford: Oxford University Press, 88-106.

Haeberli, Eric (2005). 'Clause type asymmetries in Old English and the syntax of verb movement', in Montserrat Batllori, Maria-Lluïsa Hernanz, Carme Picallo, and Francesc Roca (eds), Grammaticalization and parametric variation. Oxford: Oxford University Press, 267-283.

Heiden, Serge, Céline Guillot, Alexei Lavrentiev, and Lauranne Bertrand (2010). Base de Français Médiéval. Lyon: ENS.

Hinterhölzl, Roland, and Svetlana Petrova (2009). 'From V1 to V2 in West Germanic', Lingua 120, 315-328.

Hirschbühler, Paul, and Marie-Odile Junker (1988). 'Remarques sur les sujets nuls en subordonnées en ancien et en moyen français', Revue Québécoise de linguistique théorique et appliquée 7, 63-84.

Holmberg, Anders (2015). 'Verb second', in Tibor Kiss and Artemis Alexiadou (eds), Syntax: an international handbook of contemporary research, $2^{\text {nd }}$ edn. Berlin: Walter de Gruyter.

Hooper, Joan and Sandra Thompson (1973). 'On the applicability of root transformations', Linguistic Inquiry 4, 465-497.

Hrafnbjargarson, Gunnar Hrafn, and Anna-Lena Wiklund (2009). 'General Embedded V2: Icelandic A, B, C, etc.', Working Papers in Scandinavian Syntax 84, 21-51. 
Ingham, Richard (2012). 'A Derivational Approach to Negative Polarity Item Licensing in Old French', in Deborah L, Arteaga (ed), Research on Old French: The State of the Art. Dordrecht: Springer, 261-281.

Jespersen, Otto (1949). A Modern English grammar, vol. 7. Copenhagen: Ejnar Munksgaard.

Julien, Marit (2007). 'Embedded V2 in Norwegian and Swedish', Working Papers in Scandinavian Syntax 80, 103-161.

Julien, Marit (2009). Embedded clauses with main clause word order in Mainland Scandinavian. lingbuzz/000475.

Karttunen, Lauri (1971). 'Some observations on factivity', Papers in Linguistics 4, 55-69.

van Kemenade, Ans (1987). Syntactic case and morphological case in the history of English. Dordrecht: Foris.

van Kemenade, Ans (1997). 'V2 and embedded topicalization in Old and Middle English', in Ans van Kemenade and Nigel Vincent (eds), Parameters of morphosyntactic change. Cambridge: Cambridge University Press, 326-352.

van Kemenade, Ans, and Marit Westergaard (2012). 'Syntax and information structure: verb second variation in Middle English', in Anneli Meurman-Solin, María José López-Couso, and Bettelou Los (eds), Information structure and syntactic change in the history of English. Oxford: Oxford University Press, 87-118.

van Kemenade, Ans, and Tanja Milićev (2012). 'Syntax and discourse in Old and Middle English word order', in Dianne Jonas, John Whitman and Andrew Garrett (eds), Grammatical change: origins, nature, outcomes. Oxford: Oxford University Press, 239-254.

Koopman, Willem (1995). 'Verb-final main clauses in Old English prose', Studia Neophilologica 67, 129-144.

Labelle, Marie (2007). 'Clausal architecture in early Old French', Lingua 117, 289-316.

Ledgeway Adam (2012). From Latin to Romance: Morphosyntactic Typology and Change, Oxford, Oxford University Press.

Legendre, Géraldine, and Antonella Sorace (2003). 'Auxiliaires et intransitivité en français et dans les langues romanes', in Danièle Godard (ed), Les langues romanes. Problèmes de la phrase simple. Paris: CNRS éditions, 185-233.

Maling, Joan (1980). 'Inversion in embedded clauses in Modern Icelandic', Íslenskt mál og almenn málfrceði 2, 175-193.

Mathieu, Éric (2009). 'On the Germanic properties of Old French', in Paola Crisma and Giuseppe Longobardi (eds), Historical Syntax and Linguistic Theory. Oxford: Oxford University Press, 344357.

Mikkelsen, Line (2010). On what comes first in a verb-second language. Ms. UC Berkeley.

Mohr, Sabine (2009). 'V2 as a single-edge phenomenon,' in Kleanthes K. Grohmann and Phoevos Panagiotidis (eds), Selected papers from the 2006 Cyprus Syntaxfest. Newcastle-upon-Tyne: Cambridge Scholars Publishing, 141-158.

Müller, Gereon (2004). 'Verb-second as vP-first', Journal of Comparative Germanic Linguistics 7, 179-234.

Paoli, Sandra (2007). 'The fine structure of the left periphery: COMPs and subjects. Evidence from Romance', Lingua 117, 1057-1079.

Pintzuk, Susan (1993). 'Verb seconding in Old English: verb movement to Infl', The Linguistic Review $10,5-35$.

Pintzuk, Susan (1999). Phrase structures in competition: Variation and change in Old English word order. New York: Garland.

Pintzuk, Susan, and Eric Haeberli (2008). 'Structural variation in Old English root clauses', Language Variation and Change 20, 367-407.

Poletto, Cecilia (2002). 'The left periphery of V2 Rhaetoromance dialects: a new view on V2 and V3', in Sjef Barbiers, Leonie Cornips, and Susanne van der Kleij (eds), Syntactic Microvariation. Amsterdam: Meertens Institute Electronic Publications in Linguistics, 214-242.

Ribeiro, Ilza, and Maria A. Torres Morais (2012). 'Doubling-que embedded constructions in Old Portuguese: a diachronic perspective', in Charlotte Galves, Sonia Cyrino, Ruth Lopes, Filomena Sandalo, and Juanito Avelar (eds), Parameter theory and linguistic change. Oxford: Oxford University Press, 97-116.

Richter, Frank, and Manfred Sailer (1998). 'Complementizers and finite verbs in German sentence structure', in Tibor Kiss and Detmar Meurers (eds), Proceedings of the ESSLLI-98 Workshop on Current Topics in Constraint-based Theories of Germanic Syntax. Saarbrücken: University of Saarbrücken, 133-148. 
Rinke, Esther, and Jürgen M. Meisel (2009). 'Subject inversion in Old French: Syntax and information structure', in Georg Kaiser and Eva-Maria Remberger (eds), Proceedings of the Workshop "Nullsubjects, expletives, and locatives in Romance”. Konstanz: Fachbereich Sprachwissenschaft, 93130.

Rizzi, Luigi (1997). 'The fine structure of the left periphery', in Liliane Haegeman (ed), Elements of grammar. Dordrecht: Kluwer, 281-337.

Roberts, Ian (1993). Verbs and diachronic syntax. Dordrecht: Kluwer.

Roberts, Ian (1996). 'Remarks on the Old English C-system and the diachrony of V2', in Ellen Brandner and Gisela Ferraresi (eds), Language change and generative grammar. Linguistische Berichte, Sonderheft 7. Opladen: Westdeutscher Verlag, 154-164.

Roberts, Ian (2004). 'The C-system in Brythonic Celtic languages, V2, and the EPP', in Luigi Rizzi (ed), The cartography of syntactic structures, vol 2: The structure of CP and IP. Oxford: Oxford University Press, 297-328.

Rögnvaldsson, Eiríkur, and Höskuldur Thráinsson (1990). 'On Icelandic word order once more', in Joan Maling and Annie Zaenen (eds), Modern Icelandic syntax. San Diego: Academic Press, 3-40.

Rouveret Alain (2004). 'Les clitiques pronominaux et la périphérie gauche en ancien français', Bulletin de la Société de linguistique de Paris XCIX 1, 181-237.

Salvesen, Christine Meklenborg (2011). 'Stylistic Fronting and remnant movement in Old French', in Janine Berns, Haike Jacobs, and Tobias Scheer (eds), Romance Languages and Linguistic Theory 2009: selected papers from 'Going Romance' Nice 2009. Amsterdam: John Benjamins, 323-342.

Salvesen, Christine Meklenborg (2013). 'Topics and the left periphery: a comparison of Old French and Modern Germanic', in Terje Lohndal (ed), In search of Universal Grammar: from Old Norse to Zoque. Amsterdam: John Benjamins, 131-171.

Salvesen, Christine Meklenborg (2014a). Licensing pro in Old French. Ms. University of Oslo.

Salvesen, Christine Meklenborg (2014b). 'Le complémenteur que et la périphérie gauche. Analyse diachronique', Syntaxe et Sémantique 15, 47-80.

Salvesen, Christine Meklenborg, and Kristin Bech (2014). 'Postverbal subjects in Old English and Old French', Oslo Studies in Language 6, 201-227.

Santorini, Beatrice (1994). 'Some similarities and differences between Icelandic and Yiddish', in David Lightfoot and Norbert Hornstein (eds), Verb movement. Cambridge: Cambridge University Press, 87-106.

Schøsler, Lene, and Pieter van Reenen (2000). 'The pragmatic functions of the Old French particles AINZ, APRES, DONC, LORS, OR, PUIS, and SI', in Lene Schøsler, Susan C. Herring, and Pieter van Reenen (eds), Textual Parameters in Older Languages. Amsterdam: John Benjamins, 59-105.

Schwartz, Bonnie D., and Sten Vikner (1989). 'All verb second clauses are CPs', Working Papers in Scandinavian Syntax 43, 27-49.

Schwartz, Bonnie D., and Sten Vikner (1996). 'The verb always leaves IP in V2 clauses', in Adriana Belletti and Luigi Rizzi (eds), Parameters and Functional Heads. Oxford: Oxford University Press, 11-63.

Sells, Peter (2001). Structure, alignment and optimality in Swedish. Stanford: CSLI Publications.

Speyer, Augustin (2008). Topicalization and clash avoidance: on the interaction of prosody and syntax in the history of English with a few glimpses at German. Ph.D. dissertation. University of Pennsylvania.

Speyer, Augustin (2010). Topicalization and stress clash avoidance in the history of English. Berlin: Mouton de Gruyter.

Steiner, B. Devan (2014). The evolution of information structure and verb second in the history of French. Ph.D. dissertation. University of Indiana.

Taylor, Ann, Anthony Warner, Susan Pintzuk, and Frank Beths (2003). York-Toronto-Helsinki Parsed Corpus of Old English Prose.

Thurneysen, Rudolf (1892). 'Zur Stellung des Verbums im Altfranzösischen', Zeitschrift für romanische Philologie 16, 289-307.

Travis, Lisa de Mena (1984). Parameters and effects of word order variation. PhD dissertation. MIT.

Travis, Lisa de Mena (1991). 'Parameters of phrase structure and verb-second phenomena', in Robert Freidin (ed), Principles and parameters in comparative grammar. Cambridge, MA: MIT Press, 339-364.

Vance, Barbara (1989). 'The evolution of pro-drop in Medieval French', in Carl Kirschner and Janet DeCesaris (eds), Studies in Romance Linguistics. Amsterdam: John Benjamins, 413-441.

Vance, Barbara (1997). Syntactic change in medieval French: verb-second and null subjects. Dordrecht: Kluwer. 
Vance, Barbara, Bryan Donaldson, and B. Devan Steiner (2010). 'V2 loss in Old French and Old Occitan. The role of fronted clauses,' in Sonia Colina, Anxton Olarrea, and Ana Maria Carvalho (eds), Romance linguistics 2009: Selected Papers from the 39th Linguistic Symposium on Romance Languages. Amsterdam: John Benjamins, 301-320.

Vanelli, Laura, Lorenzo Renzi, and Paola Benincà (1986). 'Typologie des pronoms sujets dans les langues romanes', Actes du XVIIème Congrès International de Linguistique et de Philologie Romanes, vol. 3: Linguistique descriptive: phonétique, morphologie et lexique. Aix: Université de Provence, 161-176.

Vikner, Sten (1995). Verb movement and expletive subjects in the Germanic languages. Oxford: Oxford University Press.

Villa-García, Julio (2012). 'Characterizing Medial and Low Complementizers in Spanish: Recomplementation que and "jussive/optative" que', in Melvin González-Rivera and Sandro Sessarego (eds), Current Formal Aspects of Spanish Syntax and Semantics. Newcastle: Cambridge Scholars Publishing, 198-229.

Walkden, George (2009). The comparative method in syntactic reconstruction. MPhil dissertation. University of Cambridge.

Walkden, George (2014). Syntactic reconstruction and Proto-Germanic. Oxford: Oxford University Press.

Westergaard, Marit (2005). 'Norwegian child language and the history of English: The interaction of syntax and information structure in the development of word order', in Kevin McCafferty, Tove Bull, and Kristin Killie (eds), Contexts - historical, social, linguistic: studies in celebration of Toril Swan. Bern: Peter Lang, 293-310.

Zwart, C. Jan-Wouter (1991). 'Clitics in Dutch: evidence for the position of INFL', Groninger Arbeiten zur germanistischen Linguistik 33, 71-92.

Zwart, C. Jan-Wouter (1993). Dutch syntax: a Minimalist approach. PhD dissertation. University of Groningen. 